\title{
Male Aphrodisic Screening of Plants Mucuna Prurita, Mesua Ferrea, Punica Granatum on Rats
}

\author{
Sonu Sharma*, Dr. Ashish K. Sharma \\ Nims Institute of Pharmacy, Nims University, Shobha Nagar Jaipur.
}

\begin{abstract}
India has a rich culture of medicinal herbs and spices, including Ayurvedic, Unani, Siddha and other traditional medicines but only very few have been studied chemically and pharmacologically for their potential medicinal value. According to the World Health Organization, most populations still rely on traditional medicines for their psychological and physical health requirements. Herbal medicines are in great demand in both developed and developing countries as a source of primary health care owing to their attributes having wide biological and medicinal activities, high safety margins and lesser costs. As far as population growth is concerned India will be the leading country within few years of time span. Current pandemic population explosion demands an immediate betterment of new potential contraception. Thus, there is growing need to look for aphrodisiac more from natural plant or herbal origin as opposed to synthetic compounds which are known to cause severe unwanted side effects. In this regard, we have taken the plants Mucunaprurita, Mesuaferrea, punicagranatumthat has been used traditionally as antifertility agent in women and aphrodisiac, so that the couples without issue may be benefited for better acceptance in society and they may have better psychological health. In these plants so many secondary metabolites are present i.e carbohydrates, glycocides, alkaloids, tannins, phytosteroletc.All these three plants have pharmacological activity like Astringent, anthelimentic, nervine tonic, aphrodisiac, diuretic, vermifuge and stimulant, anodyne, antidotal, psychedelic, leucorrhea, spermatorrhea, facial paralysis and powerfully aphrodisiac, leprosy, scabies, skin diseases, pruritus, haemorrids, ulcers, depsia, impotency, leucorrhoea, haemoptysis, cephalalgia, fever and cardiac debility.
\end{abstract}

Keywords: Pruritus, Haemorrids, Ulcers, Depsia, Impotency, Leucorrhoea, Haemoptysis, Cephalalgia, Fever , Cardiac Debility.

\section{Introduction}

As far as population growth is concerned India will be the leading country within few years of time span. Current pandemic population explosion demands an immediate betterment of new potential contraception. ${ }^{1}$ Family planning has been promoted through several methods of contraception, including oral contraceptives. Therefore, there is a need of drug which is effective but with lesser side effects. ${ }^{2}$ Global search on anti-fertility agents is going on, to tackle the problem of population explosion. Many hormonal drugs are available for the purpose but they are not free from side effects. Hence, the search for a suitable product from indigenous medicinal plants is proposed which could be effectively used in the place of oral Pills. ${ }^{3}$

India has a rich culture of medicinal herbs and spices, including Ayurvedic, Unani, Siddha and other traditional medicines but only very few have been studied chemically and pharmacologically for their potential medicinal value. According to the World Health Organization, most populations still rely on traditional medicines for their psychological and physical health requirements. Herbal medicines are in great demand in both developed and developing countries as a source of primary health care owing to their attributes having wide biological and medicinal activities, high safety margins and lesser costs. ${ }^{4}$ The practice of traditional medicine for the control of fertility in most parts of Africa is based on the use of plant medicines for many years. The fact that the herbal medicines have been employed for such a long time there are no reports on both ethno botanical and pharmacological profile of these plants. ${ }^{5}$ In fertility regulation; the ancient literature has mentioned the use of a number of plants/preparations as abortifaciant and local contraceptives. WHO and ICMR provide systemic guidelines for the evaluation of anti-fertility plants to generate reproducible results, i.e., proper authentication and systemic screening methods. Many plant preparations are reported to possess antifertility properties in ancient Indian literature. Many plants have been tested for their anti-fertility activity in laboratory animals. Only one plant through vascicine from Adhatodavasika have been claimed to have abortifaciant properties but it could not be used clinically; the centchroman, non hormonal oral contraceptives also has not been proved very successful in phase IV clinical trials. Hence, the search needs to be continued. ${ }^{6}$ this may reduce the population burden of our country.

Aphrodisiacs are the substances which are used to increase sexual activity and help in fertility. Sexual feelings are an inevitable part of life. The basic and fundamental purpose of sex and sexuality is the "continuation of progeny" and the survival of human race. ${ }^{7}$ the sex is the most intimate, indispensable and an 
integral part of every individual and can be a source of pleasure and fulfillment. The sexual myths and misconception also leads to sexual dysfunctions. ${ }^{8}$

Infertility is a worldwide medical and social problem. It affects above $10-15 \%$ of married couples. WHO estimates that there is 60-80 million infertile couples worldwide. ${ }^{9}$ Infertility in itself may not only threaten physical health but it can certainly have a serious impact on the mental and social wellbeing of infertile couple, especially in our country. In many countries the stigma of infertility often leads to marital disharmony, divorce or ostracism. ${ }^{10}$ Research during the past two decades has an unfolded focus on impotence (erectile failure), premature ejaculation and male infertility. There are a number of prescription drugs which may act as sex stimulant and enhancing the sexual desire and activity in both men and women, although their use have shown significant improvement in treating sexual disorders, but at the same time they are not devoide of large number of side effects. These include arrhythmia, suicidal tendencies, mental disorders, tremors etc. The use of synthetic aphrodisiacs results in the dilatation of blood vessels in other parts of the body also, causing headache and even fainting. Other side effects include facial flushing, blurred vision and sensitivity to light which usually occur at higher doses. ${ }^{11}$

Thus, there is growing need to look for aphrodisiac more from natural plant or herbal origin as opposed to synthetic compounds which are known to cause severe unwanted side effects. In this regard, we have taken the plants Mucunaprurita, Mesuaferrea, punicagranatumthat has been used traditionally as antifertility agent in women and aphrodisiac, so that the couples without issue may be benefited for better acceptance in society and they may have better psychological health.

\section{PLANT PROFILE}

\section{Mucunaprurita}

Family:

Leguminosae

Common name:

KaunchBeej

Habitat:

It is found almost all over the country

Parts used:

Seeds, roots and legumes

Pharmacological action:

Astringent, anthelimentic, nervine tonic, aphrodisiac, diuretic, vermifuge and stimulant, anodyne, antidotal, psychedelic, leucorrhea, spermatorrhea, dyspepsia, colic, hemiplegic, and facial paralysis and powerfully aphrodisiac. ${ }^{12}$

\section{Chemical Constituents:}

L-dopa, sulphur, manganese, 4-dihydroxy phenylalanine, glutathayon, lacithine, galic acid and glucoside. These seeds contain saturated fatty acid stearic and palmitic acid, oliac acid and linolinic acid. ${ }^{13}$

\section{Therapeutic classification index:}

Digestive system: it is used in intestinal worms and colic

Central nervous system: it is used in paralysis, hemiplegia and other nervine disorders and spasms associated with Parkinson's or Bell's palsy.

Genito- urinary system: it is used in leucorrhea and profuse menstruation

Reproductive system: it is used as an aphrodisiac and used in seminal weakness, spermatorrhea. ${ }^{14}$

\section{Mesuaferrea}

Common name :

Nagkeshar

Family :

Guttiferae

Habitat :

Eastern Himalayas, Assam, West Bengal, Western Ghats, Travancore, and Andaman

Parts used:

Flower (stamen), oil, bark, leaf, bud, seed.

Medicinal uses :

It has astringent, digestant, and ant poisonous, antimicrobial, anti-inflammatory, antipyretic and anthelminthic. it is used in fever, itching, nausea, leprosy, skin disorders, erysipelas, bleeding piles, metrorrhagea, menorrhagea, excessive thirst, and sweating

\section{Uses as home remedy:}

1. In bleeding piles, it should be used in the dose of $3 \mathrm{gm}$ along with mishri.

2. Its oil should be use externally to cure skin disorders. 
3. Its paste or dusting of its powder is very effective to get relief from excessive sweating.

\section{Chemical composition:}

Mesuol, mammeisin, mamiflegin, mesuolsitosterol, octadecatriefloic, hexadecanolic. 1, 5-dihydroxyxanthone (ii), euxanthone 7-methyl ether (iv) and $\beta$-sitosterol, mesuanic acid, $\alpha$ - and $\beta$ - amyrin, $\beta$ - sitosterol, mesuol, mesuaferrol, Leucoanthocyanidin, mesuone, mammeigin.

\section{Medicinal properties:}

Digestive, carminative, constipating, anthelminthic, diuretic, expectorant, stomachic, haemostatic, aphrodisiac, febrifuge and cardiotonic. They are useful in asthma, cough, hiccough, leprosy, scabies, skin diseases, pruritus, pharyngodynia, vomiting, dysentery, haemorrids, ulcers, depsia, impotency, leucorrhoea, haemoptysis, cephalalgia, fever and cardiac debility. The seed oil is used in skin diseases. Pericarp of fruit is astringent and stomachic. ${ }^{15}$

\section{Circulatory system-}

Cardiac tonic and haemostatic, it is used in cardiac debility, rakta pitta and blood disorders.

\section{Central nervous system-}

Brain tonic it is useful in brain debility and hysteria.

Respiratory system-

It is used in cough induced by kapha, dyspnoea and hiccougs as it alleviates kapha.

\section{Reproductive system-}

It is used as an aphrodisiac and as a haemostatic in menorrhagia.

Digestive system-

It is appetizer, mainly digestive, antidipsetic, antiemetic, antihaemorrhoid, astringent and vermicide; hence it is used in anorexia, distaste, depsia, emesis, worms, bleeding piles, dysentery. It acts as a haemostatic in bleeding piles.

Urinary system-

Diuretic, hence useful in retention of urine. ${ }^{16}$

\section{PunicaGranatum}

Common Name :

Annar

Family Name :

Lythraceae

Part Used :

Seed, Roots, Leaves

Habitat :

Southern Europe, Northen Africa, tropical Afrika, Central asia, India, America, california

Constituents:

Vitamin C, vitamin K, polyphenols, such as ellagitannins and flavonoids, Pomegranate seed oil

contains punicic acid, palmitic acid, stearic acid, oleic acid and linoleic acid .Juice, seeds and peel apparently contain steroid hormones, including estrone. ${ }^{17,18}$

Uses: Diarrhea, dysentery and intestinal parasites. The seeds and juice are considered a tonic for the heart and throat, Especially when sweet, pomegranate fruit is nourishing for (pitta or fire) systems and is known as a blood builder. The astringent qualities of the flower juice, rind and tree bark are considered valuable for a variety of purposes, such as stopping nose bleeds and gum bleeds, toning skin, firming-up sagging breasts, and treating hemorrhoids. Pomegranate juice (of specific fruit strains) is also used as an eye drop, as it is believed to slow the development of cataracts. Pomegranate has been used as a contraceptive and abortifaciant by means of consuming the seeds, or rind, as well as by using the rind as a vaginal suppository. This practice is recorded in ancient Indian literature, in medieval sources, and in modern folk medicin. ${ }^{19}$

\section{MALE APHRODISIAC ACTIVITY ${ }^{20,21}$}

An aphrodisiac is defined as an agent that arouses sexual desire. Many natural substances have historically been known as aphrodisiac. Sexual dysfunction is a repeated inability to achieve normal sexual intercourse, which includes various forms like premature ejaculation, retrograded, or retarded ejaculation, erectile dysfunction, arousal difficulties, etc. Several management options employed are associated with some serious side effects and are not readily available and expensive. The search for natural supplement from medicinal plants is being intensified, probably because of reduced side effect, its ready availability and reduced cost. Therefore, the increasing used for search and screening of medicinal plants with aphrodisiac potential in male has been necessitated. 


\section{Materials and Methods}

1.1. Animals

Healthy Wistar strain male albino rats, two months old and weighing 200- 300 gm were used in this study. They were procured from animal house, College of Pharmacy, NIMS University, Jaipur. The animals were acclimatized for ten days under laboratory conditions. They were housed in polypropylene cages and maintained at $27^{\circ} \mathrm{C} \pm 2{ }^{\circ} \mathrm{C}$, relative humidity $65 \pm 10 \%$ under a 12 -hour light/dark cycle. The animals were fed with rodent pellet diet and water ad libitum. Animal ethical clearance for performing the experiments on animals was obtained from the Institutional Animal Ethical Committee (IAEC). Each experimental group had a separate set of animals and care was taken to ensure that animals used for one response were not employed elsewhere. Animals were habituated to laboratory conditions for $48 \mathrm{~h}$ prior to experimental protocol which minimizes any nonspecific stress.

\subsection{Acute Toxicity Study}

The acute toxicity for ethanol extracts of Mucunaprurita, Mesuaferrea, Punicagranatum and there combinations i.e Combination A(Mucunaprurita+Mesuaferrea), Combination B(Mesuaferrea +Punicagranatum), Combination C(Mucunaprurita + Punicagranatum)and Combination D(Mucunaprurita + Mesuaferrea +Punicagranatum)was determined in albino mice, maintained under standard conditions. The animals fasted overnight prior to the experiment, and fixed dose method was adopted as per OECD Guideline no. 420 - fixed dose method.

\subsection{Mating Behavior Test}

\section{Experimental Study}

The test was carried out by the methods of Dewsbury and Davis Jr and Szechtman et al modified by Amin et al. Healthy and sexually experienced male albino rats (200- $300 \mathrm{~g})$ that were showing brisk sexual activity were selected for the study. They were divided into 9 groups of 6 animals each and kept singly in separate cages during the experiment. Group 1 represented the control group, which received $10 \mathrm{ml} / \mathrm{kg}$ of distilled water orally. Group 2 served as standard and was given suspension of sildenafil citrate (Vigora tablets, German Remedies) orally at the dose of $5 \mathrm{mg} / \mathrm{kg}, 1$ hour prior to the commencement of the experiment. Groups 3-9 received ethanolic extract (and there combinations $A, B$ and $C$ ) of selected plants orally at the doses of $200 \mathrm{mg} / \mathrm{kg}$, respectively, daily for 21 days at 18:00 hour. Since the male animals should not be tested in unfamiliar circumstances hence the animals were brought to the laboratory and exposed to dim light at the stipulated time of testing daily for 6 days before the experiment. The female animals were artificially brought into oestrus (heat) by the Szechtman et al method (as the female rats allow mating only during the estrus phase). They were administered suspension of ethinyloestradiol (Lynoral tablets, OrganonPharma) orally at the dose of $100 \mu \mathrm{g} / \mathrm{animal}, 48$ hour prior to the pairing plus progesterone (Dubaget tablets, GlenmarkPharma) injected subcutaneously, at the dose of $1 \mathrm{mg} / \mathrm{animal}, 6$ hour before the experiment. The receptivity of the female animals was confirmed before the test by exposing them to male animals, other than the control, experimental and standard animals. The most receptive females were selected for the study. The experiment was carried out on the 21 st day after commencement of the treatment of the male animals. The experiment was conducted at 20:00 hour in the same laboratory and under the light of same intensity. The receptive female animals were introduced into the cages of male animals with 1 female to 1 male ratio. The observation for mating behaviour was immediately commenced and continued for first 2 mating series. The test was terminated if the male failed to evince sexual interest. If the female did not show receptivity she was replaced by another artificially warmed female. The occurrence of events and phases of mating were recorded on audio video-cassette (Sony Handycam) as soon as they appeared. Their disappearance was also recorded. Later, the frequencies and sexual behaviour phases were determined from cassette transcriptions: number of mounts before ejaculation or Mounting Frequency (MF), number of intromission before ejaculation or Intromission Frequency (IF), time from the introduction of female into the cage of the male up to the first mount or Mounting Latency (ML), time from the introduction of the female up to the first intromission by the male or Intromission Latency (IL), time from the first intromission of a series up to the ejaculation or Ejaculatory Latency (EL) and time from ejaculation and the first intromission of the following series or Post-ejaculatory interval.

Using the above parameters of sexual behaviour, the following computed parameters were calculated:

$\%$ index libido $=($ number mated $/$ number paired $) \times 100$;

$\%$ Mounted $=($ number mounted $/$ number paired $) \times 100$;

$\%$ Intromitted $=($ number of rats that intromitted $/$ number paired $) \times 100$,

Intromission ratio= (number of intromission/ number of mount + number of intromission $)$,

$\%$ Ejaculated $=($ number of rats that ejaculated/ number paired $) \times 100$;

Copulatory Efficiency $=($ number of intromission/ number of mounts $) \times 100$; Intercopulatory Efficiency= (average time between intromissions) 


\subsection{Test for Libido}

The test was carried out by the method of Davidson modified by Amin et al .Healthy and sexually experienced male albino rats $(200-300 \mathrm{~g})$ that were showing brisk sexual activity were selected for the study. They were divided into 9 groups of 6 animals each and kept singly in separate cages during the experiment. Group 1 represented the control group, which received $10 \mathrm{ml} / \mathrm{kg}$ of distilled water orally. Group 2 served as standard and was given suspension of sildenafil citrate (Vigora tablets, German Remedies) orally at the dose of $5 \mathrm{mg} / \mathrm{kg}$, 1 hour prior to the commencement of the experiment. Groups 3- 9 received ethanolic extract (and there combinations $A, B$ and $C$ ) of selected plants orally at the doses of $200 \mathrm{mg} / \mathrm{kg}$, respectively, daily for 21 days at 18:00 hour. The female rats were made receptive by hormonal treatment and all the animals were accustomed to the testing condition as previously mentioned in mating behaviour test. The animals were observed for Mounting Frequency (MF) on the evening of 21st day at 20:00 hour. The penis was exposed by retracting the sheath and 5\% xylocaine ointment (Lidocaine ointment, AstraZeneca Pharma) was applied 30, 15 and 5 min before starting the observations. Each animal male was placed individually in a cage and the receptive female rat was introduced in the same cage. The number of mountings, intromission and ejaculation were noted.

\subsection{Orientation Activity}

The test was carried out by the method of Sharma et al, modified by Islam et al . Healthy and sexually experienced male albino rats $(200-300 \mathrm{~g})$ that were showing brisk sexual activity were selected for the study. They were divided into 9 groups. Group 1 represented the control group, which received $10 \mathrm{ml} / \mathrm{kg}$ of distilled water orally. Group 2 served as standard and was given suspension of sildenafil citrate (Vigora tablets, German Remedies) orally at the dose of $5 \mathrm{mg} / \mathrm{kg}$, 1 hour prior to the commencement of the experiment. Groups 3-9 received ethanolic extract (and there combinations $A, B$ and $C$ ) of selected plants orally at the doses of $200 \mathrm{mg} / \mathrm{kg}$, respectively, daily for 21 days at 18:00 hour. The orientation activity was carried out on the 21st day of treatment and was analyzed in three segments with little modification .

Orientation behaviour of male rats was determined using following method of scoring:

- Orientation towards female - (1 for every sniffing and 2 for every licking)

- Orientation towards self - (1 for every non-genital grooming and 2 for every genital grooming)

- Orientation towards environment - (1 for every exploration, 2 for every rearing and 3 for every climbing)

The cumulative score for each orientation behavior noted in the half hour observation period was later calculated.

\subsection{Effect on Sexual and Vital Organ Weight}

After the mating behavior analysis, the next morning (Day 22), all the control, standard and experimental groups of male rats were evaluated for their body weight. The animals were completely anaesthetized with anesthetic ether (NarsonsPharma), sacrificed by cervical decapacitation and then testis, seminal vesicles, epididymis, vas-deference, penis and prostate glands along with vital organ like liver, kidney, adrenal gland, and spleen were carefully removed and weighed using digital electronic balance .

\section{Statistical Methods}

All the data are expressed as mean \pm S.E. Statistical analysis was done by Student's t-test and one way ANOVA

\subsection{Acute Toxicity Study}

\section{Results}

Clinical toxicity symptoms such as respiratory distress, salivation, weight loss and change in appearance of hair as well as maternal mortality were not observed at any period of the experiment. Similarly no mortality and changes in the behavioural, neurological and autonomic profile were observed in treated groups of the rats up to highest dose of $2000 \mathrm{mg} / \mathrm{kg}$ body weight. Hence one tenth of treated dose $(200 \mathrm{mg} / \mathrm{kg} \mathrm{b}$. w.) was selected for present investigation.

\subsection{Effect of the Extract on Mating Behaviour}

Table 1 Effect of the Extract on Mating Behaviour

\begin{tabular}{|l|l|l|l|l|l|l|l|}
\hline Treatment Group & \multicolumn{9}{|c|}{ PARAMETERS } \\
\hline & $\begin{array}{l}\text { Dose } \\
\text { (mg/kg/ } \\
\text { body } \\
\text { weight) }\end{array}$ & $\begin{array}{l}\text { Mount } \\
\text { Frequency(M } \\
\text { F) }\end{array}$ & $\begin{array}{l}\text { Mount } \\
\text { Latency } \\
\text { (in Sec) }\end{array}$ & $\begin{array}{l}\text { Intromissio } \\
\text { n } \\
\text { Frequency } \\
\text { (IF) }\end{array}$ & $\begin{array}{l}\text { Intromissi } \\
\text { on Latency } \\
\text { (in Sec) }\end{array}$ & $\begin{array}{l}\text { Ejaculation } \\
\text { Frequency } \\
\text { (EF) }\end{array}$ & $\begin{array}{l}\text { Ejaculati } \\
\text { on } \\
\text { Latency } \\
\text { (in Sec) }\end{array}$ \\
\hline Group- I Control & Vehicle & $4.5 \pm 0.66$ & $\begin{array}{l}248.6 \pm 11 \\
.7\end{array}$ & $4.33 \pm 0.68$ & $341.4 \pm 1.76$ & $1 \pm 0.25$ & $\begin{array}{l}262.8 \pm 5.7 \\
3\end{array}$ \\
\hline $\begin{array}{l}\text { Group- II } \\
\text { Sildenafil citrate }\end{array}$ & 5 & $6.5 \pm 0.36^{* * *}$ & $\begin{array}{l}138.6 \pm 7 . \\
2 *\end{array}$ & $\begin{array}{l}5.66 \pm 0.33^{*} \\
* *\end{array}$ & $\begin{array}{l}142.19 \pm 6.6 \\
* * *\end{array}$ & $2.5 \pm 0.42^{* * *}$ & $\begin{array}{l}454.3 \pm 15 . \\
6 * * *\end{array}$ \\
\hline Group- III & 200 & $8.5 \pm 1.77^{* *}$ & $246.8 \pm 6$. & $9.83 \pm 1.89 *$ & $228.4 \pm 10.5$ & $1.83 \pm 0.30 \mathrm{~ns}$ & $407.4 \pm 16$. \\
\hline
\end{tabular}


Male Aphrodisic Screening Of Plants Mucuna Prurita, Mesua Ferrea, Punica Granatum On Rats

\begin{tabular}{|c|c|c|c|c|c|c|c|}
\hline $\begin{array}{l}\text { Ethanolic Extract } \\
\text { of Mucunaprurita }\end{array}$ & & & $5 \mathrm{~ns}$ & & $*$ & & $8 * *$ \\
\hline $\begin{array}{l}\text { Group- IV } \\
\text { Ethanolic Extract } \\
\text { of Mesuaferrea }\end{array}$ & 200 & $16 \pm 1.75 * * *$ & $\begin{array}{l}180 \pm \\
11.1 * * *\end{array}$ & $\begin{array}{l}19.16 \pm 3.14 \\
* * *\end{array}$ & $\begin{array}{l}186.4 \pm 17.2 \\
*\end{array}$ & $2 \pm 0.36^{* *}$ & $\begin{array}{l}484.2 \pm 10 \\
9.2 *\end{array}$ \\
\hline $\begin{array}{l}\text { Group- V } \\
\text { Ethanolic Extract } \\
\text { of } \\
\text { Punicagranatum }\end{array}$ & 200 & $4.66 \pm 0.61 \mathrm{~ns}$ & $\begin{array}{l}202.2 \pm 10 \\
.8 *\end{array}$ & $16 \pm 0.57 * *$ & $\begin{array}{l}281.1 \pm 25.8 \\
* *\end{array}$ & $1.66 \pm 0.40 * *$ & $\begin{array}{l}256.8 \pm 64 . \\
8 \mathrm{~ns}\end{array}$ \\
\hline $\begin{array}{l}\text { Group- VI } \\
\text { Ethanolic Extract } \\
\text { of Combination A }\end{array}$ & 200 & $5.5 \pm 0.92 *$ & $\begin{array}{l}176.6 \pm 15 \\
.4 * * *\end{array}$ & $18 \pm 2.75 * *$ & $\begin{array}{l}189.3 \pm 22.2 \\
* * *\end{array}$ & $2.33 \pm 0.33 * * *$ & $\begin{array}{l}320.4 \pm 10 \\
0.2 * * *\end{array}$ \\
\hline $\begin{array}{l}\text { Group- VII } \\
\text { Ethanolic Extract } \\
\text { of Combination B }\end{array}$ & 200 & $7.16 \pm 0.60$ *** & $\begin{array}{l}163.2 \pm 49 \\
.8 * * *\end{array}$ & $\begin{array}{l}20.66 \pm 1.26 \\
* * *\end{array}$ & $\begin{array}{l}206.5 \pm 36.6 \\
* * *\end{array}$ & $1.33 \pm 0.21 \mathrm{~ns}$ & $\begin{array}{l}300.6 \pm 6 * \\
*\end{array}$ \\
\hline $\begin{array}{l}\text { Group- VIII } \\
\text { Ethanolic Extract } \\
\text { of Combination C }\end{array}$ & 200 & $3.83 \pm 0.47 *$ & $\begin{array}{l}393.6 \pm 33 \\
* *\end{array}$ & $\begin{array}{l}5.83 \pm 0.47 \\
n s\end{array}$ & $\begin{array}{l}661.2 \pm 173 . \\
4 * * *\end{array}$ & Absent & Absent \\
\hline $\begin{array}{l}\text { Group- IX } \\
\text { Ethanolic Extract } \\
\text { of Combination D }\end{array}$ & 200 & $\begin{array}{l}25.66 \pm \\
4.98 * * *\end{array}$ & $\begin{array}{l}129.2 \pm 16 \\
.1 * * *\end{array}$ & $\begin{array}{l}21.5 \pm 3.33 * \\
* *\end{array}$ & $156 \pm 10.9 * *$ & $2.5 \pm 0.30 * * *$ & $\begin{array}{l}846.6 \pm 58 . \\
8 * * *\end{array}$ \\
\hline
\end{tabular}

Values in Mean \pm S.E. (Standard error), $\mathbf{n}=6, * \mathbf{P}<0.05, * * \mathbf{P}<0.01, * * * \mathbf{P}<0.001$, when compared with control, ns- non significant.
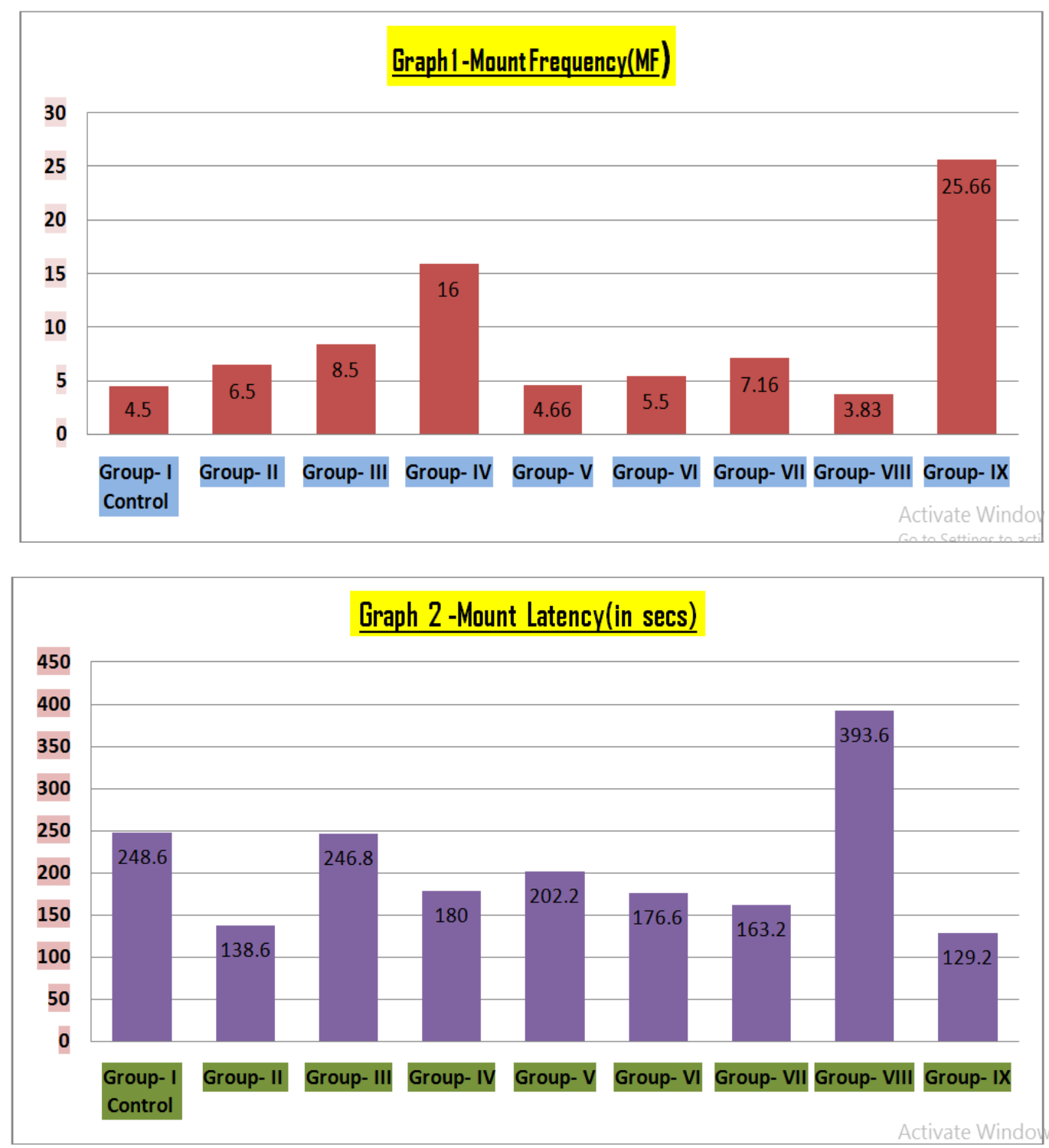

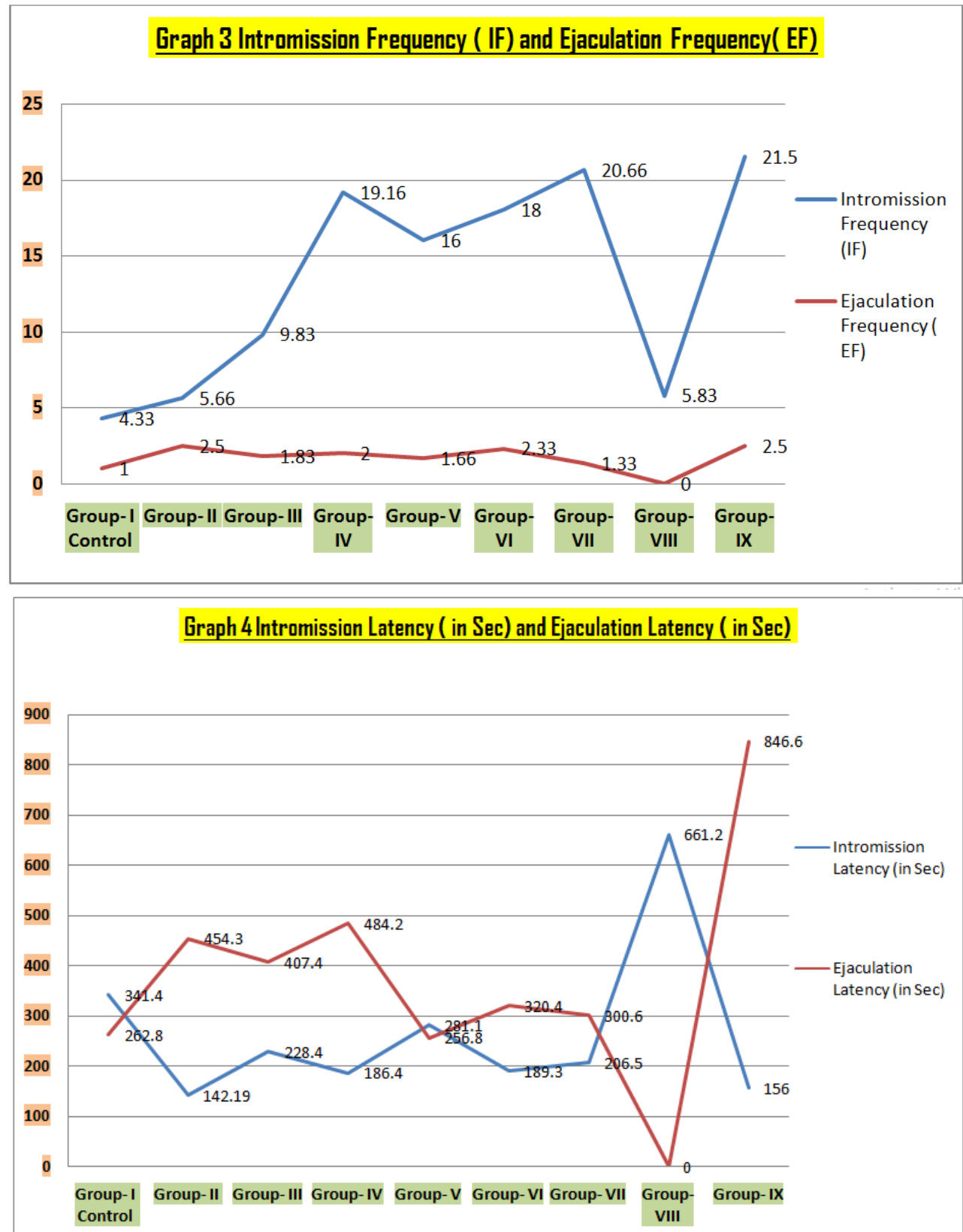

TABLE 2: Effect Of Ethanolic Extracts Of Selected Plants There Combinations On Computed Male Rat Sexual Behaviour Parameters

\begin{tabular}{|c|c|c|c|c|c|c|c|c|}
\hline \multirow{2}{*}{ Treatment groups } & \multicolumn{8}{|c|}{ Parameters } \\
\hline & $\begin{array}{l}\text { Doses } \\
(\mathrm{mg} / \mathrm{kg} \\
\text { Body wt) }\end{array}$ & $\begin{array}{l}\text { \% Index of } \\
\text { libido }\end{array}$ & $\begin{array}{l}\% \\
\text { Mounted }\end{array}$ & $\begin{array}{l}\% \\
\text { Intromit } \\
\text { ted }\end{array}$ & $\begin{array}{l}\text { Intromi } \\
\text { ssion } \\
\text { ratio }\end{array}$ & $\begin{array}{l}\text { \%Ejacul } \\
\text { ated }\end{array}$ & $\begin{array}{l}\text { \% } \\
\text { Copula } \\
\text { rory } \\
\text { Efficie } \\
\text { ncy }\end{array}$ & $\begin{array}{l}\text { Intercopulator } \\
\text { y interval (in } \\
\text { sec) }\end{array}$ \\
\hline $\begin{array}{l}\text { Group- I } \\
\text { Control }\end{array}$ & Vehicle & 66.66 & 66.66 & 83.66 & 0.49 & 67 & 100 & $721 \pm 10.8$ \\
\hline $\begin{array}{l}\text { Group- II } \\
\text { Sildenafil citrate }\end{array}$ & 5 & 83.33 & 100 & 100 & 0.50 & 100 & 100 & $306.6 \pm 21.7 * * *$ \\
\hline $\begin{array}{l}\text { Group- III } \\
\text { Ethanolic Extract of } \\
\text { Mucunaprurita }\end{array}$ & 200 & 100 & 100 & 83.33 & 0.53 & 100 & 100 & $154.8 \pm 21.8 * * *$ \\
\hline $\begin{array}{l}\text { Group- IV } \\
\text { Ethanolic Extract of } \\
\text { Mesuaferrea }\end{array}$ & 200 & 66.66 & 50 & 50 & 0.67 & Absent & 100 & $254.4 \pm 6^{* * *}$ \\
\hline $\begin{array}{l}\text { Group- V } \\
\text { Ethanolic Extract of } \\
\text { Punicagranatum }\end{array}$ & 200 & 66.66 & 66.66 & 83.33 & 0.73 & Absent & 100 & $377.6 \pm 9.4 * * *$ \\
\hline
\end{tabular}


Male Aphrodisic Screening Of Plants Mucuna Prurita, Mesua Ferrea, Punica Granatum On Rats

\begin{tabular}{|l|l|l|l|l|l|l|l|l|}
\hline $\begin{array}{l}\text { Group- VI } \\
\text { Ethanolic Extract of } \\
\text { Combination A }\end{array}$ & 200 & 100 & 100 & 100 & 0.76 & 100 & 100 & $141 \pm 11.2^{* * *}$ \\
\hline $\begin{array}{l}\text { Group- VII } \\
\text { Ethanolic Extract of } \\
\text { Combination B }\end{array}$ & 200 & 100 & 100 & 100 & 0.45 & 100 & 83.78 & $130 \pm 23.9^{* * *}$ \\
\hline $\begin{array}{l}\text { Group- VIII } \\
\text { Ethanolic Extract of } \\
\text { Combination } \boldsymbol{C}\end{array}$ & 200 & 100 & 100 & 100 & 0.54 & 100 & 100 & $153.6 \pm 14.23 * *$ \\
\hline $\begin{array}{l}\text { Group- IX } \\
\text { Ethanolic Extract of } \\
\text { Combination D }\end{array}$ & 200 & 100 & 100 & 100 & 0.74 & 100 & 100 & $366 \pm 3.66^{* *}$ \\
\hline
\end{tabular}

Values in Mean \pm S.E. (Standard error), $\mathbf{n}=6, * \mathbf{P}<0.05, * * \mathbf{P}<0.01, * * * \mathbf{P}<0.001$, when compared with control, ns- non significant.

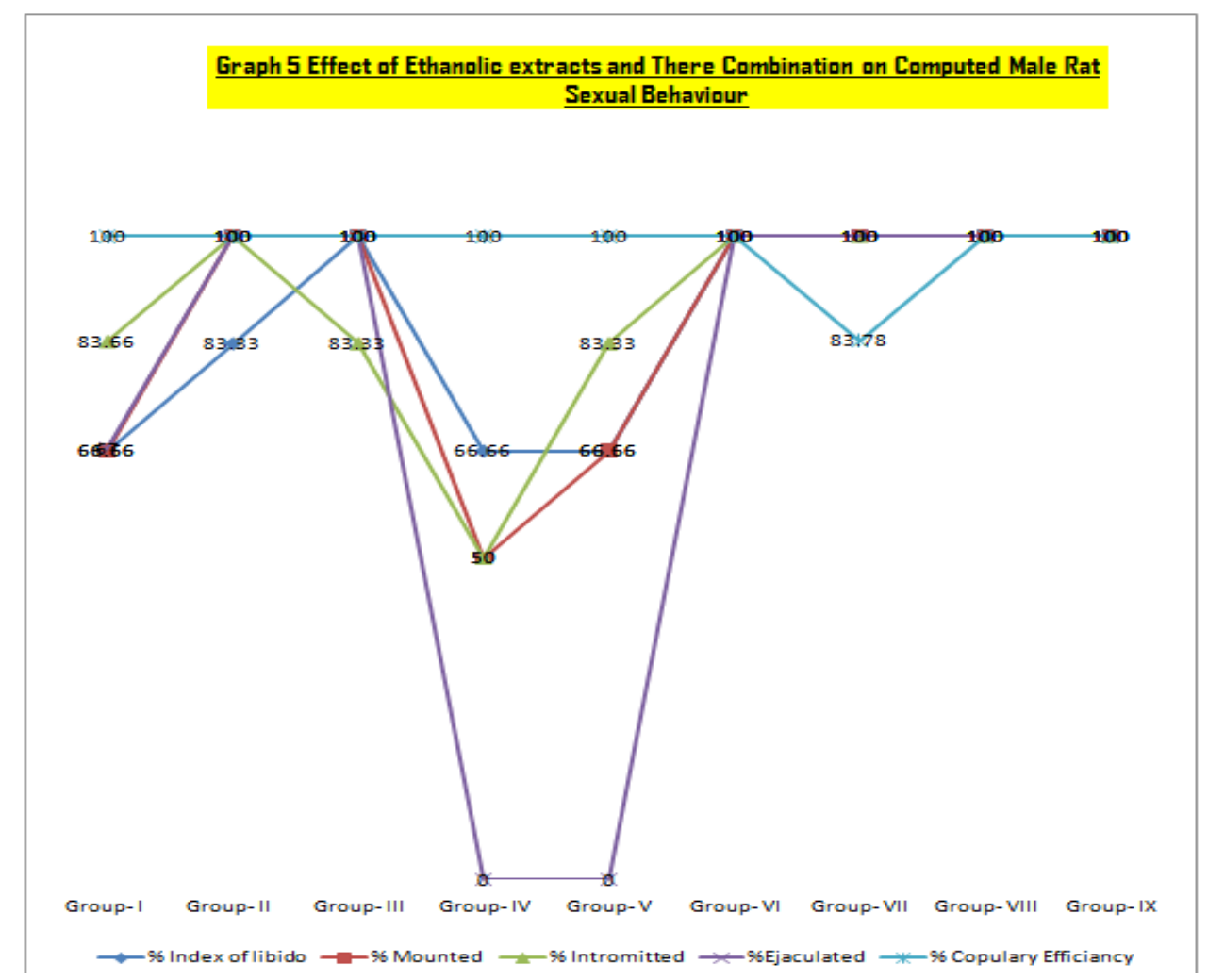

\subsection{Effect of the Extract on Libido}

TABLE 3: Effect Of Ethanolic Extracts Of Selected Plants There Combinations On On Mounting Frequency

(Test For Libido) In Male Rats

\begin{tabular}{|l|l|l|l|l|}
\hline \multirow{2}{*}{ Treatment groups } & \multicolumn{3}{|c|}{ Parameters } \\
\cline { 2 - 5 } & $\begin{array}{l}\text { Doses (mg/kg } \\
\text { Body wt) }\end{array}$ & $\begin{array}{c}\text { Mounting Frequency } \\
\text { (MF) }\end{array}$ & $\begin{array}{c}\text { Intromission } \\
\text { Frequency (IF) }\end{array}$ & Ejaculation (EJ) \\
\hline $\begin{array}{l}\text { Group- I } \\
\text { Control }\end{array}$ & Vehicle & $4.8 \pm 0.47$ & $4 \pm 0.36$ & Absent \\
\hline $\begin{array}{l}\text { Group- II } \\
\text { Sildenafil citrate }\end{array}$ & 5 & $17.83 \pm 0.70^{* * *}$ & $9.5 \pm 0.56^{* * *}$ & Present \\
\hline $\begin{array}{l}\text { Group- III } \\
\text { Ethanolic Extract of } \\
\text { Mucunaprurita }\end{array}$ & 200 & $8.5 \pm 0.88^{*}$ & $8.33 \pm 1.05 \mathrm{~ns}$ & Present \\
\hline $\begin{array}{l}\text { Group- IV } \\
\text { Ethanolic Extract of } \\
\text { Mesuaferrea }\end{array}$ & 200 & $8.83 \pm 1.70^{* *}$ & $12 \pm 1.75^{* *}$ & Present \\
\hline $\begin{array}{l}\text { Group- V } \\
\text { Ethanolic Extract of } \\
\text { Punicagranatum }\end{array}$ & 200 & $7.5 \pm 0.42^{*}$ & $14.5 \pm 0.45^{* * *}$ & Absent \\
\hline $\begin{array}{l}\text { Group- VI } \\
\text { Ethanolic Extract of } \\
\text { Combination } \boldsymbol{A}\end{array}$ & 200 & $13.66 \pm 0.93^{* * *}$ & $17.16 \pm 0.91^{* * *}$ & Present \\
\hline
\end{tabular}


Male Aphrodisic Screening Of Plants Mucuna Prurita, Mesua Ferrea, Punica Granatum On Rats

\begin{tabular}{|l|l|l|l|l|}
\hline $\begin{array}{l}\text { Group- VII } \\
\text { Ethanolic Extract of } \\
\text { Combination B }\end{array}$ & 200 & $17 \pm 1.79^{* * *}$ & $19.83 \pm 0.45^{* * * *}$ & Present \\
\hline $\begin{array}{l}\text { Group- VIII } \\
\text { Ethanolic Extract of } \\
\text { Combination } \boldsymbol{C}\end{array}$ & 200 & $10 \pm 1.46^{* * * *}$ & $12.66 \pm 2.10^{* * * *}$ & Present \\
\hline $\begin{array}{l}\text { Group- IX } \\
\text { Ethanolic Extract of } \\
\text { Combination } \boldsymbol{D}\end{array}$ & 200 & $28.33 \pm 5.4^{* * *}$ & $24.16 \pm 2.54 * * *$ & Present \\
\hline
\end{tabular}

Values in Mean \pm S.E. (Standard error), $\mathbf{n}=6, * \mathbf{P}<0.05, * * \mathbf{P}<0.01, * * * \mathbf{P}<0.001$, when compared with control, ns- non significant.

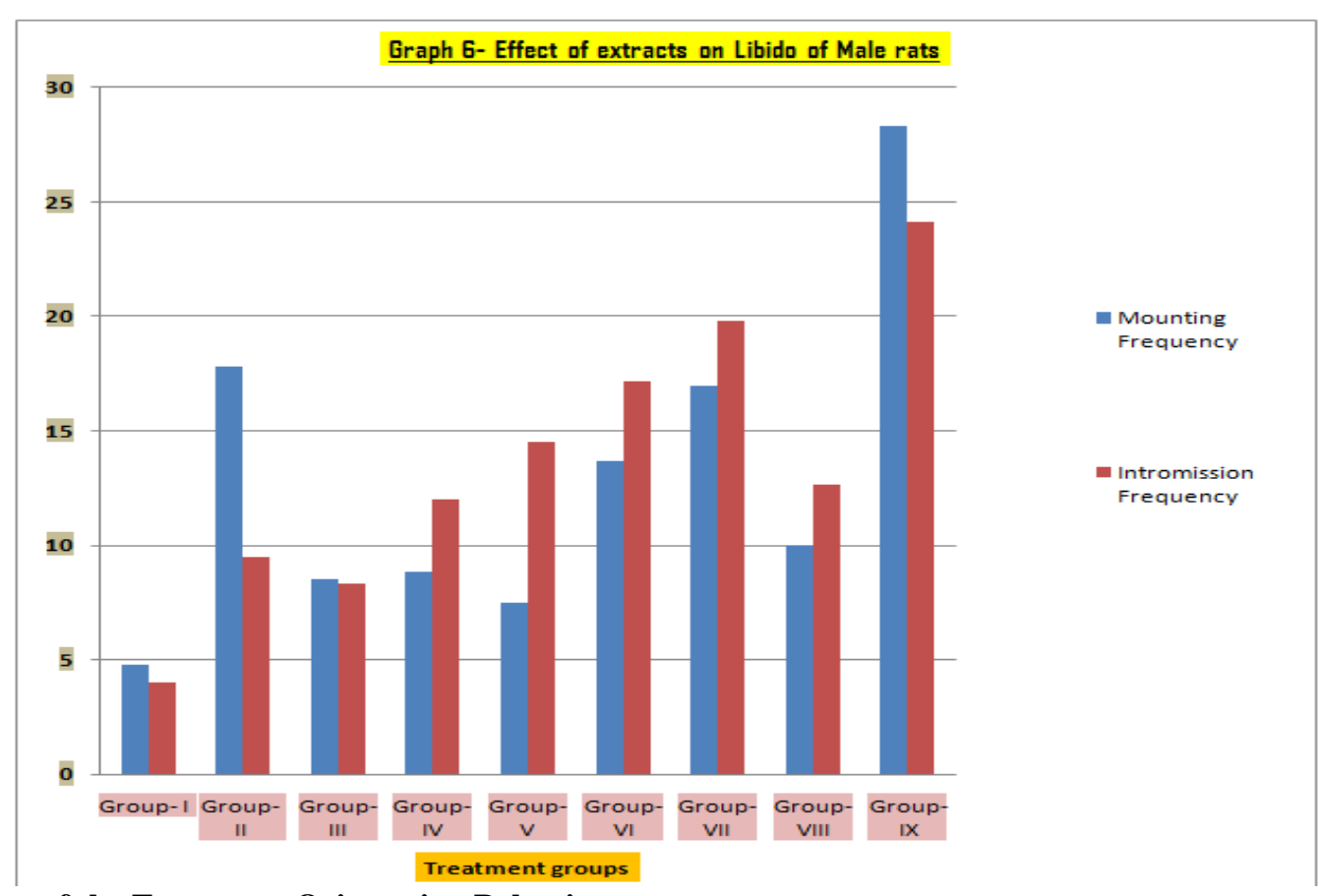

4.4 Effect of the Extract on Orientation Behaviour

TABLE 4: Effect Of Ethanolic Extracts Of Selected Plants There Combinations On Orientation Activity In Male Rats

\begin{tabular}{|c|c|c|c|c|c|c|c|c|}
\hline \multirow{3}{*}{$\begin{array}{l}\text { Treatment } \\
\text { groups }\end{array}$} & \multicolumn{8}{|c|}{ Parameters } \\
\hline & \multirow[b]{2}{*}{$\begin{array}{l}\text { Doses } \\
\text { (mg/kg } \\
\text { Body } \\
\text { wt) }\end{array}$} & \multicolumn{2}{|c|}{$\begin{array}{l}\text { Mean activity score towards } \\
\text { Female }\end{array}$} & \multicolumn{3}{|c|}{ Mean activity score towards Environment } & \multicolumn{2}{|c|}{$\begin{array}{l}\text { Mean activity Score towards } \\
\text { Self }\end{array}$} \\
\hline & & \begin{tabular}{|l} 
Licking \\
\end{tabular} & $\begin{array}{l}\text { Anogenital } \\
\text { smelling }\end{array}$ & Exploration & \begin{tabular}{|l} 
Rarring \\
\end{tabular} & \begin{tabular}{|l} 
Climbing \\
\end{tabular} & $\begin{array}{l}\text { Nongenital } \\
\text { grooming }\end{array}$ & $\begin{array}{l}\text { Genital } \\
\text { grooming }\end{array}$ \\
\hline $\begin{array}{l}\text { Group-I } \\
\text { Control }\end{array}$ & Vehicle & $17 \pm 0.85$ & $11 \pm 0.73$ & $23.33 \pm 1.66$ & $27.33 \pm 1.42$ & $05 \pm 1.24$ & $22.16 \pm 0.98$ & $28 \pm 0.33$ \\
\hline $\begin{array}{l}\text { Group-II } \\
\text { Sildenafil } \\
\text { citrate }\end{array}$ & 5 & $26.5 \pm 1.57^{* * * *}$ & $23 \pm 0.70^{* * * *}$ & $19 \pm 0.78$ & $13 \pm 0.48^{* *}$ & $03 \pm 0.23^{* * * *}$ & $17 \pm 1.34^{* * *}$ & $36 \pm 2.42^{* * * *}$ \\
\hline $\begin{array}{l}\text { Group-III } \\
\text { Ethanolic } \\
\text { Extract of } \\
\text { Mucunaprurita }\end{array}$ & 200 & $14 \pm 0.38^{* *}$ & $13.83 \pm 0.54 \mathrm{~ns}$ & $11.5 \pm 0.33^{* * *}$ & \begin{tabular}{|l}
$16.66 \pm 0.33^{* *}$ \\
\end{tabular} & \begin{tabular}{|l|l|} 
Nil \\
\end{tabular} & $33.5 \pm 0.11^{* *}$ & $30.5 \pm 0.66^{*}$ \\
\hline $\begin{array}{l}\text { Group-IV } \\
\text { Ethanolic } \\
\text { Extract of } \\
\text { Mesuaferrea }\end{array}$ & 200 & $25 \pm 0.90^{* *}$ & $16.8 \pm 0.68^{* *}$ & $20.66 \pm 1.08^{* *}$ & $24.5 \pm 0.44^{*}$ & \begin{tabular}{|l|l} 
Nil \\
\end{tabular} & $28.5 \pm 0.22^{* *}$ & $33.3 \pm 0.38^{* *}$ \\
\hline $\begin{array}{l}\text { Group-V } \\
\text { Ethanolic } \\
\text { Extract of } \\
\text { Punicagranatum }\end{array}$ & 200 & $17 \pm 0.54 \mathrm{~ns}$ & $13 \pm 0.33 \mathrm{~ns}$ & $\begin{array}{l}22.16 \pm 0.45 \\
\mathrm{~ns}\end{array}$ & $30.5 \pm 2.05 * * *$ & $3.5 \pm 0.55 * *$ & $27.8 \pm 0.77^{*}$ & $28 \pm 1.64 \mathrm{~ns}$ \\
\hline $\begin{array}{l}\text { Group-VI } \\
\text { Ethanolic } \\
\text { Extract of } \\
\text { Combination } A\end{array}$ & 200 & $26.5 \pm 1.06^{* * * *}$ & $24.5 \pm 1.20^{* * * *}$ & $40.5 \pm 2.30^{* * * *}$ & $33.66 \pm 1.06^{* * *}$ & $4 \pm 0.16^{*}$ & $39.5 \pm 1.89 * * *$ & $36.5 \pm 1.06^{* *}$ \\
\hline $\begin{array}{l}\text { Group-VII } \\
\text { Ethanolic } \\
\text { Extract of } \\
\text { Combination } B\end{array}$ & 200 & $31.66 \pm 1.21^{* * * *}$ & $32 \pm 0.28^{* * *}$ & $21.4 \pm 0.43^{*}$ & $26.16 \pm 0.30 \mathrm{~ns}$ & Nil & $43.33 \pm 1.22^{* * * *}$ & $39 \pm 0.20 * * *$ \\
\hline $\begin{array}{l}\text { Group-VIII } \\
\text { Ethanolic } \\
\text { Extract of } \\
\text { Combination C }\end{array}$ & 200 & $19.33 \pm 0.87^{*}$ & $20 \pm 0.13^{* *}$ & $15.33 \pm 0.24^{* *}$ & $22.16 \pm 0.28^{* *}$ & \begin{tabular}{|l|} 
Nil \\
\end{tabular} & $35 \pm 0.98^{* * *}$ & $34.14 \pm 2.31^{* * * *}$ \\
\hline $\begin{array}{l}\text { Group-IX } \\
\text { Ethanolic } \\
\text { Extract of } \\
\text { Combination D }\end{array}$ & 200 & $29.33 \pm 0.16^{* * *}$ & $23.5 \pm 1.09^{* * *}$ & $22.8 \pm 0.90 \mathrm{~ns}$ & $29.8 \pm 1.05^{* *}$ & Nil & $34 \pm 0.47^{* * *}$ & $40 \pm 0.24^{* * *}$ \\
\hline
\end{tabular}

Values in Mean \pm S.E. (Standard error), $\mathbf{n}=6, * \mathbf{P}<0.05, * * \mathbf{P}<0.01, * * * \mathbf{P}<0.001$, when compared with control, ns- non significant. 


\section{Histography of Male Aprodisiac Activity}

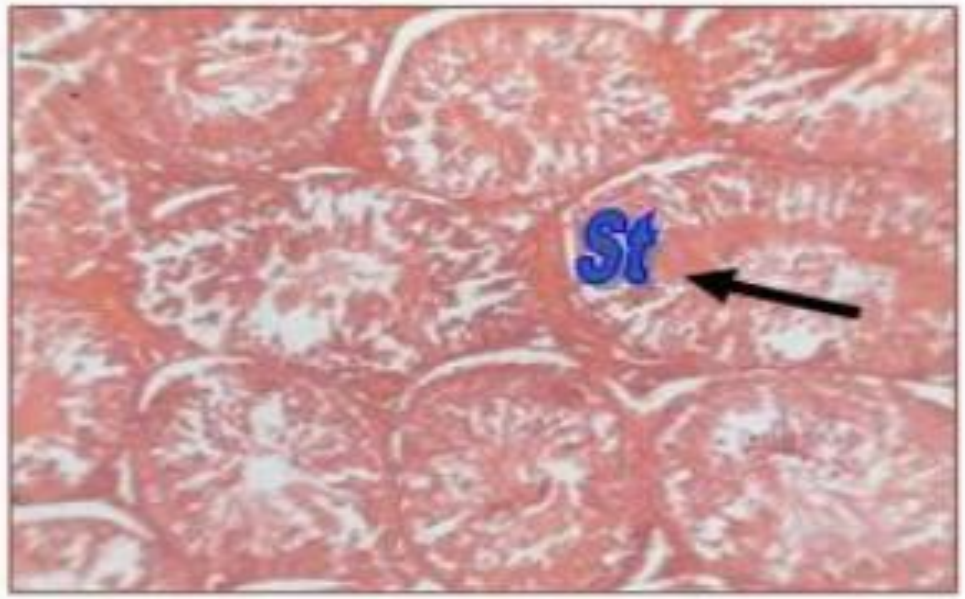

Figure 1- Testis of Control Animal (Showing well arrangedSemineferous tubules- showing alterations) H \& E $\mathrm{X} 400$

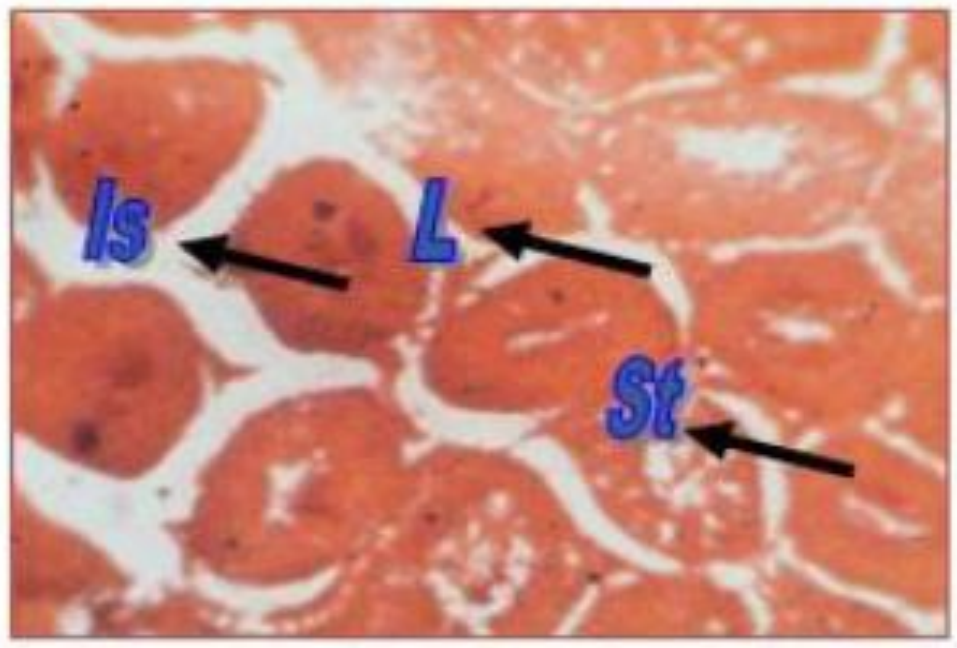

Figure 2- Testis of Group II Standard Animal (Showing -Semineferous tubules- showing alterations) H \& E X 400

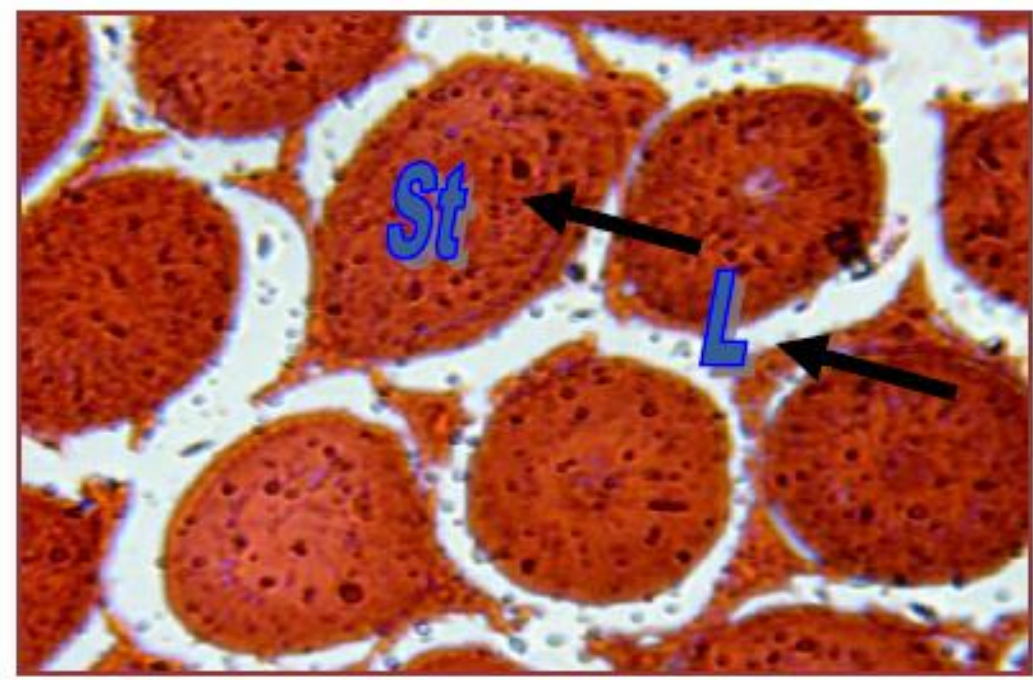

Figure 3- Testis of Group IX- Combination of Extarcts on Animal (Showing necrotic Semineferous tubulesshowing alterations) H \& E X 400 


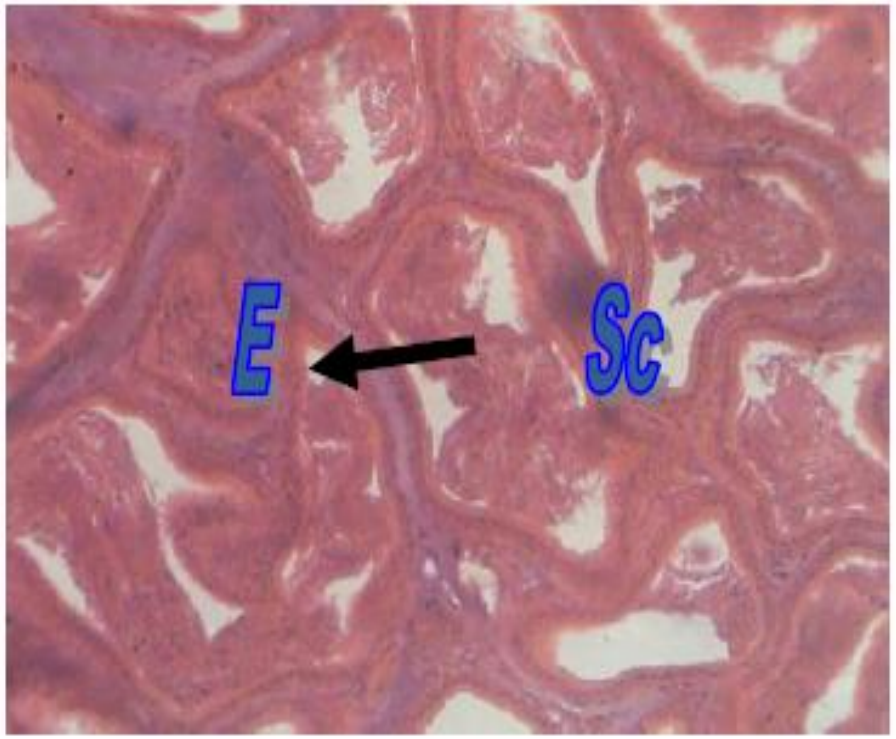

Figure 4- Epididymis of Control Animal (Showing tubules lined with well defined epithelium) H \& E X 400

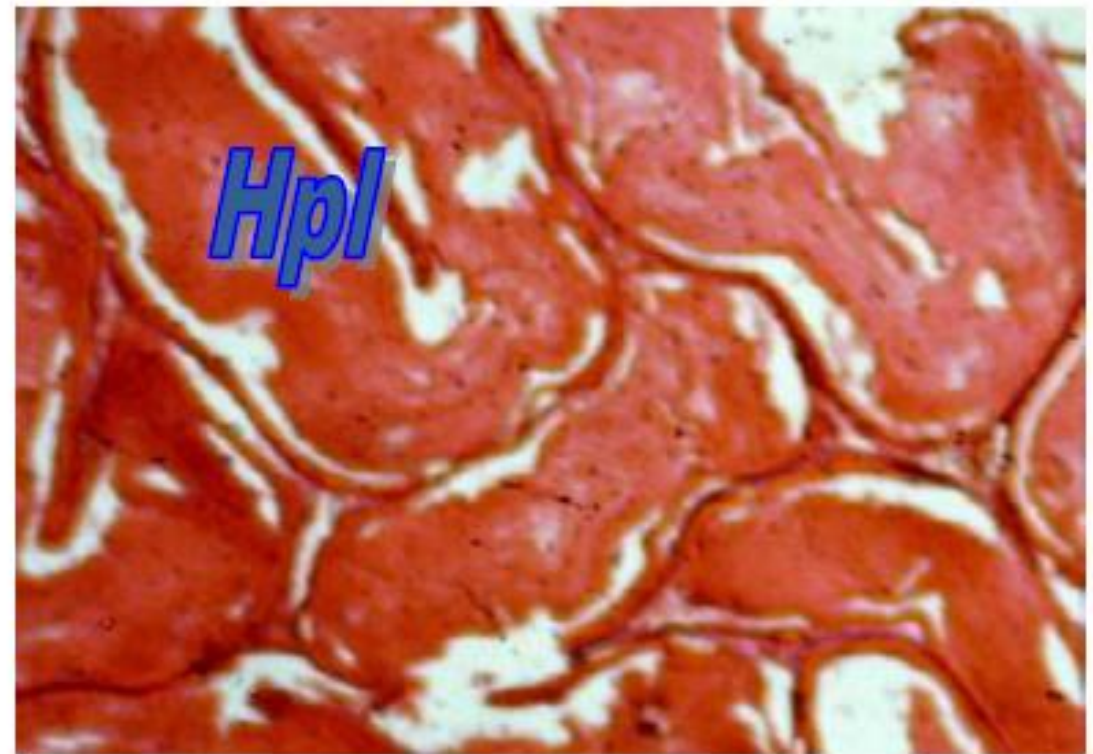

Figure 5- Epididymis of Group II Standard Animal (Showing hypertrophy of Lumen) H \& E X 400

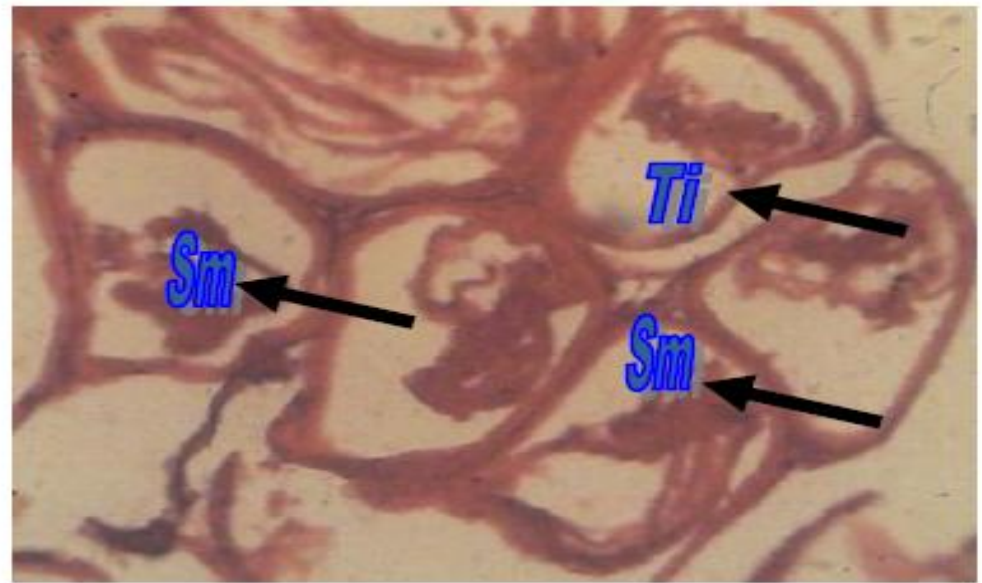

Figure 6- Epididymis of Group IX Combination D treated Animal (Showing thing epithelial lining) H \& E X 400 


\section{Conclusion}

Clinical toxicity symptoms such as respiratory distress, salivation, weight loss and change in appearance of hair as well as maternal mortality were not observed at any period of the experiment. Similarly no mortality and changes in the behavioural, neurological and autonomic profile were observed in treated groups of the rats up to highest dose of $2000 \mathrm{mg} / \mathrm{kg}$ body weight. Hence one tenth of treated dose $(200 \mathrm{mg} / \mathrm{kg} \mathrm{b}$. w.) was selected for present investigation.

Male Aphrodisiac activity was performed with following tests

Mating Behaviour Test

Using the above parameters of sexual behavior, the following computed parameters were calculated:

- $\%$ index libido $=($ number mated $/$ number paired $) \times 100$;

- $\%$ Mounted $=($ number mounted/ number paired $) \times 100$;

- \% Intromitted= (number of rats that intromitted/ number paired $) \times 100$,

- Intromission ratio= (number of intromission/ number of mount + number of intromission),

- $\%$ Ejaculated $=($ number of rats that ejaculated $/$ number paired $) \times 100$;

- Copulatory Efficiency= (number of intromission/ number of mounts $) \times 100$; Intercopulatory Efficiency= (average time between intromissions)

\section{All the parameters were found highly significant for combination C Extracts of plants}

Test for Libido

The test was carried out by the method of Davidson modified by Amin et al .Healthy and sexually experienced male albino rats $(200-300 \mathrm{~g})$ that were showing brisk sexual activity were selected for the study. They were divided into 9 groups of 6 animals each and kept singly in separate cages during the experiment. Group 1 represented the control group, which received $10 \mathrm{ml} / \mathrm{kg}$ of distilled water orally. Group 2 served as standard and was given suspension of sildenafil citrate (Vigora tablets, German Remedies) orally at the dose of $5 \mathrm{mg} / \mathrm{kg}$, 1 hour prior to the commencement of the experiment. Groups 3-9 received ethanolic extract (and there combinations $A, B$ and $C$ ) of selected plants orally at the doses of $200 \mathrm{mg} / \mathrm{kg}$, respectively, daily for 21 days at 18:00 hour.

Orientation Activity

The test was carried out by the method of Sharma et al , modified by Islam et al . Healthy and sexually experienced male albino rats $(200-300 \mathrm{~g})$ that were showing brisk sexual activity were selected for the study. They were divided into 9 groups. Group 1 represented the control group, which received $10 \mathrm{ml} / \mathrm{kg}$ of distilled water orally. Group 2 served as standard and was given suspension of sildenafil citrate (Vigora tablets, German Remedies) orally at the dose of $5 \mathrm{mg} / \mathrm{kg}$, 1 hour prior to the commencement of the experiment. Groups 3- 9 received ethanolic extract (and there combinations $A, B$ and $C$ ) of selected plants orally at the doses of $200 \mathrm{mg} / \mathrm{kg}$, respectively, daily for 21 days at 18:00 hour. The orientation activity was carried out on the 21 st day of treatment and was analyzed in three segments with little modification .

Orientation behaviour of male rats was determined using following method of scoring:

- Orientation towards female - (1 for every sniffing and 2 for every licking)

- Orientation towards self - (1 for every non-genital grooming and 2 for every genital grooming)

- Orientation towards environment - (1 for every exploration, 2 for every rearing and 3 for every climbing)

\section{Effect on Sexual and Vital Organ Weight}

After the mating behaviour analysis, the next morning (Day 22), all the control, standard and experimental groups of male rats were evaluated for their body weight. The animals were completely anaesthetized with anesthetic ether (NarsonsPharma), sacrificed by cervical decapacitation and then testis, seminal vesicles, epididymis, vas-deference, penis and prostate glands along with vital organ like liver, kidney, adrenal gland, and spleen were carefully removed and weighed using digital electronic balance .

\section{Acknowledgement}

No scientific work is even accomplished without the continuing guidance and encouragement of the investigators supervisors, or the active support and assistance of his colleagues, technical and nontechnical staff. I wish to express my deep sense of gratitude to Dr. Aashish Kumar Sharma, Principal Nims institute of pharmacy (Rajasthan) of for his active guidance, innovative ideas, constant inspiration, and untiring effects which enabled me to complete my thesis work. Let me express my profound sense of gratitude and heartful thanks to Dr. Sanjay Kumar Das , Research director and Dean, Academics studies of Nims university Jaipur (Rajasthan) for his invaluable encouragement and affectionate support, his helpful suggestion and innovative guidance gave a beautiful and constructive shape to this research work. I would like to thank Dr. K. P Singh Registrar of Nims University, and all the staff of Research cell for constant help and support.I express my deep sense of gratitude to our Managing Director ShobhaTomar, Chairman And Chancellor Balbir Singh Tomar, 
for providing all facilities and encouragement to complete this research work successfully. Words would be limited in expressing my heartful veneration to my Papa Mr. Dwarika Prasad Sharma, Mummy Mrs. Lalita Devi Sharma, Didi-Jiju, My Sweet Nieces Vaidehi, Love, Vanshul, and Sister Kavita, Bhaiya -Bhabhi And My Friends, for their constant encouragement inspiration and keen interest towards my educational carrier. I wish to thank and gratitude to my Dear Husband Mr. Lokesh Kumar Sharma for his affectionate encouragement, and moral support. On personal note, I would like to express my deep gratitude to my in laws and family members who have encouraged me during the whole tenure of my project work.

\section{References}

[1] Ghosh K and Bhattacharya T K. "Preliminary study on the anti implantation activity of compound from the extracts of seeds of thespesiapopulnea. India Journal of Pharmacology. 2004; 36 : 288-291

[2] Thakare V N, Kothavade P S, Dhote V V, Deshpande A D. Antifertility Activity of Ethanolic Extract of Allium cepaLinn in Rats. International Journal of PharmTech Research. 2009;1 : 73-78

[3] Singh Shiv Pal. Fertility Control of Female through SesbaniSesbian Seeds. The Journal of Research and Education in Indian Medicine. 1990; 9 (4): 27- 32.

[4] ShahuAlakh N. Phyto-pharmacological review of mesuaferrealinn. International Journal OfPhytopharmacology. 2014; 5(1): 6-14.

[5] Ramya R, Sivasakthi R, Senthilkumar C, Anudeepa J, Santhi N, Venkata Narayanan N: Preliminary phyto chemical and anti fertility Studies on Dodonea viscose Linn. Asian Journal Res Pharm Sci, 2011; 1 : 77-79

[6] Kachroo Monica and Agrawal S S. Anti-implantation activity of different extract of the peels of Citrus medica Linn. International Journal of PharmTech Research. 2011;3 (1): 535-539,

7] Kothari P. Common Sexual Problems. 3rd edition, UBS publishers, New Delhi, 2001; 1(6): 155, 203, $204,221$.

[8] Kar N, and Chandra G. Comprehensive Textbook of Sexual Medicine. 1st edition, Jaypee Brothers Medical Publishers. New Delhi, 2005; 280-285, 309-313.

[9] Badami S, Desai V B, Suresh B. Drugs play a major role in male fertility. Express Pharma Pulse 2000; $2: 18$

[10] Khanna J. Prevention of infertility. Office of Publication, W.H.O., Geneva, 1992; 32: 161-166.

[11] Kulkarni S K and Reddy D S. Pharmacotherapy of Male Erectile Dysfunction with Sildenafil. Indian Journal of Pharmacology. $1998 ; 30: 367-378$

[12] Kumar Pradeep, SahaSudipta. An updated review on Taxonomy. Phytochemistry, Pharmacology and Toxicology of Macunapruriens. 2013; 2 (I) 1:306-314

[13] http://www.singleherbs.org/products/kaunch.htm Retrieved on date 10-2-14 at $2.40 \mathrm{pm}$

[14] Sharma Brijesh Kumar, Ahmad Shamim, Singh Rahul, Verma Rajesh Kumar and Kumar Nilesh. A review on Mucunapruriens: Its phyto constituents and therapeutic uses, Novel Science International Journal of Pharmaceutical Science. 2012;1(6):308 -312

[15] http://www.spicesmedicinalherbs.com/mesua-ferrea.html Retrieved on date10-2-14 at $2.34 \mathrm{pm}$

[16] http://en.wikipedia.org/w/index.php?title=Nerium\&oldid=594044276" Retrieved on date 12-2-14 at 2.59 pm

[17] Heftmann, Shui-TzeKo and Raymond D. Bennett. Identification of estrone in pomegranate seeds. Erich Phytochemistry. 1966;5,(6):1337-1339,

[18] Young Lim Kho, Woong Jung, Dohyeong Kwon and Jung HoanKim.identification of estrone in pomegranate (Punicagranatum) extracts by liquid chromatography-tandem mass spectrometry. Food Science and Biotechnology,2010;19, (3):809-813,

[19] John Riddle. Contraception and Abortion from the Ancient World to the Renaissance. Harvard University Press, Cambridge, Massachusetts; London, England.1992, 25.

[20] Morakinyo A., Effects of ZingiberOfficinaleon Reproductive Functions in the Male Rat.African Journal of Biomedical Research, $2008 ; 11: 329-334$

[21] Venkatesh P, Ektha PB, Hephzibah G, Ratna DC, Neraja Y. in vivofertility enhancing activity (aphrodisiac) of ficuscaricafruit on male wistarratsInternational journal of pharmacy and pharmaceutical sciences. $2013 ; 5$ (2) : 15-18

IOSR Journal of Pharmacy and Biological Sciences (IOSR-JPBS) is UGC approved Journal with Sl. No. 5012, Journal no. 49063.

Sonu Sharma. "Male Aphrodisic Screening of Plants Mucuna Prurita, Mesua Ferrea, Punica Granatum on Rats." IOSR Journal of Pharmacy and Biological Sciences (IOSR-JPBS) 12.4 (2017): 15-27. 